\title{
Greener growing: assessing the influence of gardening practices on the ecological viability of community gardens in South East Queensland, Australia
}

\author{
Daniela A. GUITART ${ }^{1}$, Jason BYRNE ${ }^{2}$, Catherine M. PICKERING ${ }^{3}$ \\ School of Environment, Griffith University, Gold Coast, Queensland, Australia, 4222.
}

1. Research Assistant, National Climate Change Adaptation Research Facility, Griffith University, Gold Coast campus, QLD 4222, Australia. Phone: +61 75552 7547, Fax: +61 7 5552 7333, Email: d.guitart@griffith.edu.au.

2. * Correspondence Author: Senior Lecturer, School of Environment, Environmental Futures Centre, Building G31, Room 3.06, Griffith University, Gold Coast campus, QLD 4222, Australia. Phone: +61 75552 7723, Fax: +61 75552 8244, Email: jason.byrne@griffith.edu.au.

3. Associate Professor, School of Environment, Environmental Futures Centre, Building G24, Room 3.08, Griffith University, Gold Coast campus, QLD 4222, Australia. Phone: +61 7 5552 8059, Fax: +61 75552 8067, Email: c.pickering@griffith.edu.au.

\begin{abstract}
While claims about the environmental benefits of community gardens abound, few researchers have systematically assessed the ecological integrity of gardening practices. This study investigated gardening practices in fifty community gardens in Brisbane and Gold Coast cities, Australia. The study aimed to better understand how gardening practices might affect the ecological viability of community gardens. Factors investigated included: garden bio-physical characteristics, operators' motivations, gardeners' socio-demographic backgrounds, garden facilities, and types of plants grown. Two broad types of gardens were identified - permaculture (21 gardens) and non-permaculture (29 gardens). Permaculture gardens used lower-impact gardening practices. Findings have policy implications for environmental planning and management.
\end{abstract}

KEY WORDS: Food production, urban agriculture, motivations, benefits, sustainability, ecology 


\section{Introduction}

Rapid urbanisation and industrial agricultural food production have led to a growing disconnection between urban dwellers and their food sources (Clement 2010). Food safety, availability, and affordability are now widely reported concerns in both developing and developed countries (Satterthwaite et al. 2010). Land use planners, ecologists, local residents, and non-profit organisations have called for alternatives to the industrial model of food production, which is widely seen as having broadscale negative environmental impacts (Cone and Myhre 2000, Jarosz 2008). How to produce food in cities, using practices that are ecologically viable over the longer term, has become an issue of paramount importance (Heintzman and Solomon 2006, Turner 2011). Urban agriculture is receiving increased attention as a possible alternative (Altieri et al. 1999, Deelstra and Girardet 1999, Guitart et al. 2012, McClintock 2013, Taylor and Lovell 2012).

According to McClintock (2013), urban agriculture can be differentiated based on 'scale, function, labour and management', with a spectrum of garden types including: private gardens, urban allotments, roof-top food gardens, market gardens, guerrilla gardens, institutional gardens (e.g. schools or prisons) and community gardens (see also Guitart et al. 2012). Community gardens present a useful example for urban agriculture research at the local scale because such gardens typically entail collective or cooperatively organised agricultural practices, usually on public land, they may receive some form of government subsidy or assistance, they are not 'market-focused', and they can foster civic engagement (McClintock 2013). As Pearson and Firth (2012: 149) have observed: “community gardens are part of an increasing number of small-scale, bottom-up projects being led by community groups and individuals that collectively have the potential to engineer large-scale social 
change”. They also have the potential to contribute to positive environmental change (Barthel et al. 2013).

While some scholars and community garden advocates have asserted that community gardens can contribute to the long term viability of urban food systems (DeKay 1997, Ferris et al. 2001, Holland 2004, Irvine et al. 1999, Stocker and Barnett 1998, Wakefield et al. 2007, Wills et al. 2009) this claim has never been substantiated (Turner 2011). In fact very little is known about community gardening practices, their potential environmental impacts, and how different practices might contribute to sustainable urban food production. This is partly because a narrow social science research agenda has thus far dominated community garden research, and the ecological aspects of community gardens, including gardening practices, have been neglected (Guitart et al. 2012).

Researchers and policy-makers have tended to overlook the agricultural practices employed in community gardens, and how these practices are shaped by both garden characteristics, the types of people who garden, and the motivations behind developing community gardens (Guitart et al. 2012). Gardening practices may play an important role in the long term ecological viability of urban agricultural systems like community gardens because gardening practices entail the effective management of soil nutrients, sunlight, rainfall and biological resources (Taylor and Lovell 2012).

Although gardening practices can be both environmentally beneficial (e.g. composting, local sourcing of plants and materials, etc.) and environmentally harmful (e.g. use of synthetic chemical pesticides, limited plant diversity, etc.) we presently lack a systematic assessment of the ecological viability of different types of gardening practices in urban food gardens. We acknowledge that some researchers have investigated the range of agricultural food production practices used in urban agriculture and home gardens (Kortright and 
Wakefield 2009, Moreno-Black et al. 1996), but scant research exists for community gardens (Clavin 2011, Turner 2011). More information about gardening practices within community gardens can assist policy makers and land use planners in weighing up competing claims about the environmental benefits of community gardens, especially when these claims are used to justify exclusive access to public land. Our study aimed to address this knowledge gap.

This paper reports the results of research examining garden practices in community gardens in Brisbane and Gold Coast cities, the two largest cities within the South East Queensland (SEQ) region, among the most rapidly urbanising regions in Australia (Queensland Government 2009). The paper addresses five specific questions about community gardens, as a step towards better understanding the long term viability of such gardens as urban agricultural systems. These questions are: (i) what are the characteristics of community gardens including motivation, organisation and funding; (ii) what gardening practices are used in the gardens?; (iii) if there are differences in gardening practices between gardens, what factors could explain these differences?; (iv) how sustainable are the gardening practices?; and (v) how might land use policy and decision makers benefit from a better understanding of gardening practices? Lessons learned have the potential to inform environmental planning for urban agriculture in Australia and internationally.

\section{Community gardens as a form of urban agriculture}

Community gardens have become a growing source of food in cities (Endres and Endres 2009, Kurtz 2001). They date back to at least the nineteenth century garden allotments for working class residents of burgeoning industrial cities (DeSilvey 2003, Lawson 2004, Martin and Marsden 1999). During both World Wars in the United States, Britain and Australia, 
community gardens provided a reliable source of food because fresh fruits and vegetables were too expensive for families living on modest wages. Gardening was also framed as a patriotic act to help the war effort (Armstrong 2000b, Gaynor 2006, Pack 1919). After World War II, unemployment declined, wages grew, and consumption burgeoned (Barthel et al. 2013). Many productive urban garden spaces in the developed world were replaced by spaces for leisure (Bartling 2012, Gaynor 2006). Although there was a brief revival of interest in community gardens in the 1970s (associated with the growing environmental movement and the oil crisis), this was short-lived (King 2008). However, recent trends in urban densification and declining access to yard space, rising levels of physical inactivity, and increasing concerns about food security and the environmental impacts of food production, are fostering resurgent popularity of community gardening (King 2008, Turner et al. 2011). But how environmentally sustainable are these gardens? While detailed studies of community gardening practices are lacking, the international literature on community gardens identifies some broad factors relevant to assessing how gardening practices might affect the ecological viability of community gardens.

\section{Types of community of gardens}

Upon closer inspection, there is no one single type of community garden (Ferris et al. 2001, Pearson and Firth 2012, Schmelzkopf 1996), arguably reflecting the diverse motivations behind the establishment and operation of these gardens. For instance, community gardens have been established by local governments for 'community building', by urban migrants to maintain cultural practices and traditions, by environmental groups to preserve heirloom vegetables, and by neighbourhood associations to reduce crime (Saldivar-Tanaka and Krasny 2004, Shinew et al. 2004). While most community gardens are developed for food 
production, (Armstrong 2000b, Harris 2009, Holland 2004, Saldivar-Tanaka and Krasny 2004, Shinew et al. 2004, Stocker and Barnett 1998, Twiss et al. 2003), there are many other types of community gardens. For example, Schmelzkopf (1996), classified community gardens into six types: school gardens, ornamental gardens, botanical gardens, memorial gardens, family gardens and casita-based gardens (typical Puerto-Rican gardens). A later study by Ferris et al. (2001) identified eight types of garden: leisure gardens, child and school gardens, entrepreneurial gardens (to alleviate poverty), crime diversion gardens, work and training gardens, healing and therapy gardens, quiet gardens and neighbourhood pocket parks (some food is grown in such parks). This diversity of garden types reflects the motivations underpinning garden development, which in turn shape gardening practices and potentially their ecological sustainability.

Motivations behind, and benefits of, community gardens

A detailed review of community garden literature is beyond the scope of this paper (see Guitart et al. 2012 for a systematic review), however, the literature on motivations and benefits provides important insights for gardening practices. Most community garden studies identify ‘capacity building’ as the primary driver of garden development (Nettle 2010). Other important motivations include: community building (Armstrong 2000b, Holland 2004); mental or physical health promotion (Armstrong 2000a, Twiss et al. 2003, Wakefield et al. 2007); crime reduction (Saldivar-Tanaka and Krasny 2004, Schmelzkopf 1996, Shinew et al. 2004); preserving cultural heritage (Saldivar-Tanaka and Krasny 2004, Schmelzkopf 1996); and even fund raising (Holland 2004, Wakefield et al. 2007). Studies have also found that community gardens have been developed to promote: education (Somerset et al. 2005); contact with nature (Shinew et al. 2004, Stocker and Barnett 1998); sustainability (Campbell 
2004, Harris 2009, Irvine et al. 1999); relaxation (Schmelzkopf 2002); and saving money (Holland 2004). Some community gardens may also improve interracial relations (SaldivarTanaka and Krasny 2004, Shinew et al. 2004).

Yet there are notable gaps in the literature. Comparatively fewer studies have systematically surveyed gardens within a particular city or region (Armstrong 2000b, Baker 2004, Bartling 2012, Corrigan 2011, Saldivar-Tanaka and Krasny 2004, Voicu and Been 2008, Wakefield et al. 2007). The community garden literature is also geographically limited with most studies in the United States. Another limitation is there are few studies that have assessed how land tenure systems and land use planning practices can produce different outcomes for community gardens in different places, with concomitant impacts on agrobiodiversity (Guitart et al. 2012). Research on gardening practices and the environmental impact of community gardens is almost non-existent (Guitart et al. 2012). This paper seeks to address knowledge gaps about community gardens, focusing on gardening practices.

\section{Methods}

This study examined community gardens in Brisbane and Gold Coast cities, among the most rapidly urbanising cities in Australia (Figure 1). Their urban populations are expected to grow from 2.8 million in 2006 to 4.4 million people by 2031 (Queensland Government 2009). It thus sought to address problems with previous studies, which did not assess entire urban areas.

Data for this study were collected using two methods: (i) a desk-top survey of community gardens and (ii) standardised-question interviews with garden managers. The interviews were limited to garden managers rather than community gardeners for two reasons: we were interested in collective rather than individual practices, and because garden 
managers were more knowledgeable about the entire garden rather than individual plots or beds, they were better sources of information. The survey was also limited to food-producing community gardens rather than those that only grow ornamental or native-plant gardens. Data collection was also limited to those gardens located within the Brisbane and Gold Coast city municipal boundaries.

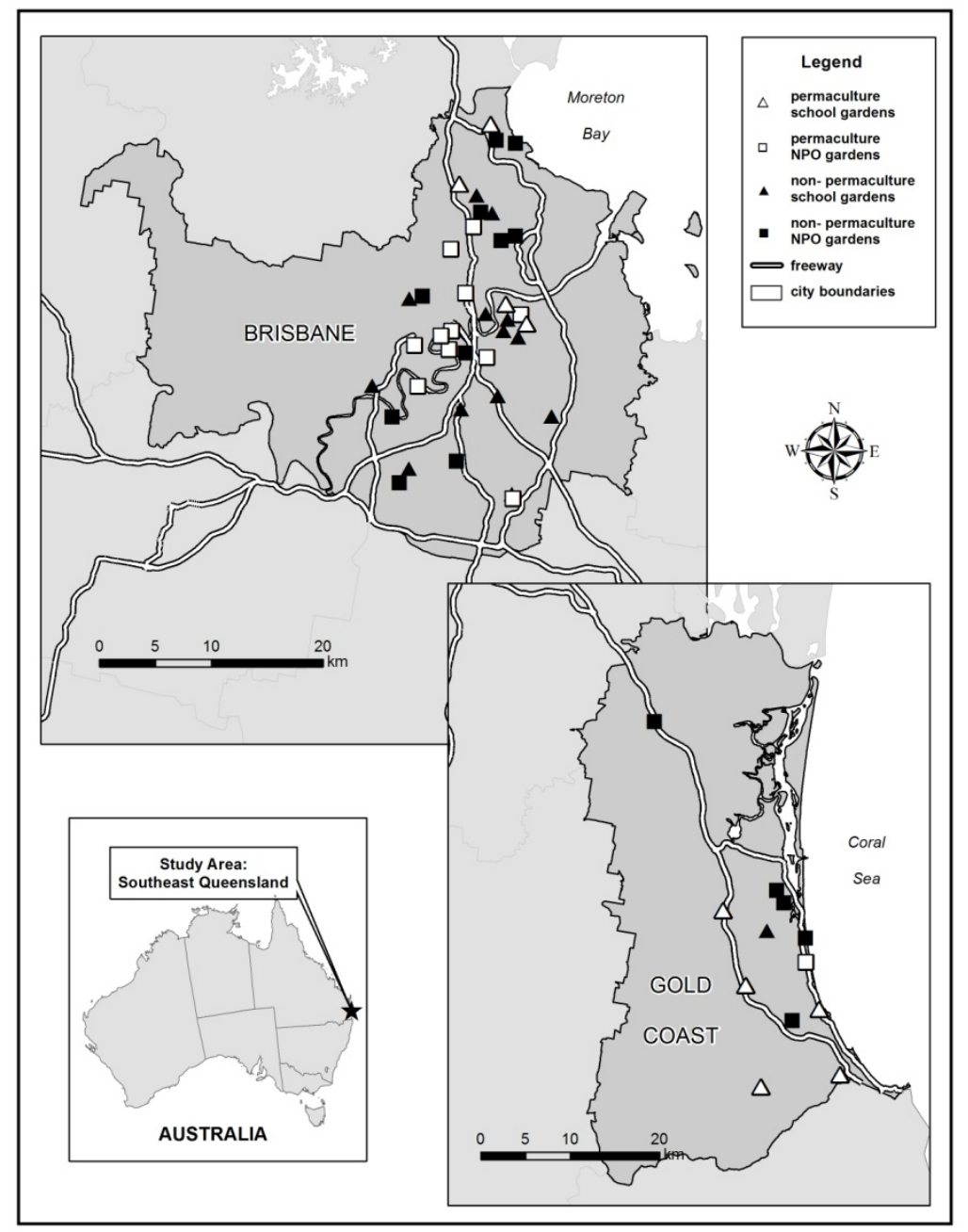

Figure 1 Location of 50 community gardens in the Brisbane and Gold Coast study area. 


\section{Study area}

We assessed community gardens within the two largest local government areas in South East Queensland - Brisbane and Gold Coast cities. These two cities are the first and second largest local government areas in Australia (respectively) and contain most of the region's population. According to our calculations, they also contain about twenty percent of Australia's community gardens. Brisbane and the Gold Coast cities have responded to growth pressures by adopting land use policies that promote urban containment, smaller lot sizes, and increased density (Byrne et al. 2010). The result has been a decrease in backyard garden size and an increase in apartment living, reducing both residents' ability to experience nature and their capacity to grow their own food; a situation that portents social and environmental problems (Hall 2010). Partly in response to these issues, both cities have actively encouraged community garden-building. ${ }^{\mathrm{i}}$

Little is known about the characteristics of, and gardening practices within, community gardens in the two cities. Factors potentially affecting gardening practices that were investigated included: the type of organisations managing the gardens, motivations underpinning garden use, membership programs, land tenure, garden age, garden sizes, garden facilities the type of plants grown, and gardeners socio-demographic characteristics (Clayton 2007, Guitart et al. 2012). The study collected data on a wide variety of factors that are potentially linked with gardening practices, because previous studies have suggested these factors may play a role in garden sustainability. For example, data were collected on the socio-demographics of gardeners because studies report that the ethno-racial background of gardeners can affect gardening practices; different cultures value different practices (Baker 2004, Corlett et al. 2003, Kingsley et al. 2009, Lautenschlager and Smith 2007). 


\section{Desk-top survey and garden audits}

The Brisbane and Gold Coast City Council websites were systematically searched to identify food producing community gardens. A list of gardens was compiled, and a web search was undertaken to determine if identified gardens had their own websites, and the type of information available on those websites. The search terms were 'community', 'gardens', 'Brisbane' and 'Gold Coast'. The first three to five Google ${ }^{\mathrm{TM}}$ result pages were examined, and all relevant websites were visited. ${ }^{\mathrm{ii}}$ A list of 40 community gardens was generated. Because this sampling method could underestimate the existence of gardens where organisations did not have web presence, a 'snowball' sampling technique was used to expand the list. Key informants including the community garden officers from Brisbane and Gold Coast City Councils were contacted, and community garden general meetings were attended to identify additional potential informants. As a cross validation method, a map was generated using Google Earth ${ }^{\mathrm{TM}}$ to show informants the location of all known community gardens so informants could identify any missing gardens. This map was later shown to garden managers for the same purpose.

A database of all community gardens within the study area was compiled; it included the garden name, physical address, postal address, and garden managers' names and contact details (i.e. phone number, email). A total of 56 community gardens were subsequently located across Gold Coast and Brisbane. However, three gardens were no longer operating (having closed after the Brisbane floods in early 2010).

Garden managers were initially contacted via telephone or email to verify that their garden qualified for the research (e.g. food plants were in the ground and the garden was currently operating) and that they wished to participate. Where there was a core group in charge of the garden, one person was selected as the contact person; other members of the 
group were encouraged to be present when the survey was completed. Three school community gardens did not have time to complete the survey. Fifty community gardens were assessed from June 2011 to August 2011. Each garden was visited to record its exact location and area, to collect the survey information, and to identify plants grown in the garden. The perimeter of each garden was walked, and a Trimble Juno ST ${ }^{\mathrm{TM}}$ hand held Global Positioning System (GPS) was used to create polygons from which the garden area could later be calculated using a Geographic Information System (GIS). Photographs were taken and the presence of facilities and gardening practices were also cross-validated.

\section{Face-to-face interviews}

Several studies have used surveys to obtain socio-demographic information about community gardens (e.g. Armstrong 2000b, Somerset et al. 2005), but none of these have investigated gardening practices. Given the small number of gardens in the study area, we opted to use semi-structured interviews to collect data. We developed a set of standardised interview (survey-style) questions, closely resembling a questionnaire, using Fink’s (2003) 'Survey Kit' as a guide. The interview instrument was approved by the home institution's human ethics committee (ENV/12/11/HREC), was pilot-tested, and was then modified based on responses.

Potential participants were given an information sheet and asked for their informed consent, which they gave by answering the interview questions. Because garden managers' roles varied between and within organisations (e.g. could be a teacher, a parent, the principal, grounds-person, garden specialist, president of the organisation, a paid worker or the most active volunteer), garden managers could answer the questions with another garden member present, to improve the accuracy of information provided. The questions were asked in person, and interviews took approximately 30-45 minutes. In some schools, teachers or 
principals had insufficient time to complete the entire set of questions during the site visit, so a pre-paid envelope was provided to enable them to return answers when time permitted.

The first part of the interview obtained general data about the community gardens. The first set of questions consisted of five multiple choice questions and two open ended questions. Questions pertained to garden age, management (organisation type, individual or communal system, land ownership and motivation), membership system (number of members, cost of membership, waiting lists, cultural backgrounds) and facilities present in the gardens (e.g. water and electricity sourcing, worm farm, compost, solar panels, nursery, toilets).

The second section of the interview consisted of 20 multiple choice questions and one open ended question. This section obtained information about gardening practices. Literature on gardening practices (Mollison 1988, Mollison 1994, Morrow 2006, Yiridoe and Anchirinah 2005) was used to generate a scale of practices ranging from less sustainable, to more sustainable. The first question in this section was about 'gardening philosophy' ${ }^{\text {iii }}$, which was then cross-validated with actual practices. Gardeners were provided with five options (organic/chemical-free, conventional, biodynamic, permaculture and other) and instructed to check all that applied. Information on gardening practices included: (i) soil nutrient improvement methods; (ii) pest control strategies; (iii) sourcing of gardening materials and (iv) sourcing of plants and seeds. Some questions provided similar information, allowing cross-validation of answers, thus increasing the reliability of the data (e.g. chemical use in gardening philosophy, soil nutrient improvement and pest management). 


\section{Analysis}

All information gathered from the interviews was entered into a database. Data was transferred to SPSS statistical packages for analysis. Two types of organisations were found to operate community gardens within the study area: schools (46\%) and non-profit organisations (NPO). The NPOs include 14 volunteer groups, six government funded community support groups, two churches, two learning disability centres, one early parenting centre, one senior centre and one police-citizens youth club. A series of chi-squared tests were used to compare the general characteristics and gardening practices between the school and non-profit gardens. To assess if there were differences in the cultural background of members of school and non-profit gardens statistical analyses were performed. The in-garden diversity of members' cultural backgrounds was compared using one-way ANOVA, while chi-squared tests were used compare differences in the number of gardens with members belonging to specific cultural groups.

Two broad types of gardening practices emerged based on reported gardening philosophy: permaculture gardens (42\%), which used techniques developed by the international permaculture movement (Mollison 1988, Mollison 1994), and non-permaculture gardens (58\%). Therefore a 'permaculture index' was created to cross validate reported gardening philosophy with the actual gardening practices used (Table 1). A list of 57 key gardening practices associated with the permaculture movement was identified based on the information from Mollison (Mollison 1988, Mollison 1994) and Morrow (2006), and a positive or negative value was assigned for each practice, with the potential range of values from + 30 to -23 (Table 1). One-way ANOVAs were used to compare the permaculture index values between gardens operated by the two types of organisations, and also to compare values between gardens based on their philosophies. A series of chi-squared tests were also 
used to compare individual garden characteristics and practices between permaculture and non-permaculture gardens.

Table 1 Gardening practices used for calculating 'permaculture index’ and their scores.

\begin{tabular}{|c|c|c|}
\hline Categories & yes & no \\
\hline \multicolumn{3}{|l|}{ Soil sourcing: } \\
\hline Build own soil & 1 & -1 \\
\hline From landscape yards (bought or donated) & -1 & 1 \\
\hline \multicolumn{3}{|l|}{ Soil improved using: } \\
\hline Commercial synthetic fertilizers & -1 & 1 \\
\hline Commercial organic fertilizers & -1 & 1 \\
\hline Homemade compost & 1 & -1 \\
\hline Worm castings & 1 & -1 \\
\hline Homemade fertilizers & 1 & -1 \\
\hline Locally sourced animal manure & 1 & -1 \\
\hline Locally grown green manure & 1 & -1 \\
\hline \multicolumn{3}{|l|}{ Weeds, pests, diseases controlled by using: } \\
\hline Commercial synthetic pesticides & -1 & 1 \\
\hline Homemade natural pesticides & 1 & -1 \\
\hline Soap & -1 & 1 \\
\hline Specific planting to attract beneficial insects & 1 & -1 \\
\hline Companion planting & 1 & -1 \\
\hline Using highly diverse plant species & 1 & -1 \\
\hline Maintaining healthy soil & 1 & -1 \\
\hline Keeping animals & 1 & -1 \\
\hline Planting in season/climate & 1 & -1 \\
\hline Crop rotating & 1 & -1 \\
\hline \multicolumn{3}{|l|}{ Type of mulch used: } \\
\hline Don't use mulch & -1 & 1 \\
\hline Commercial mulch & -1 & 1 \\
\hline Commercial animal manure & -1 & 1 \\
\hline $\begin{array}{l}\text { Straw, lucerne hay, green manure from } \\
\text { garden }\end{array}$ & 1 & -1 \\
\hline Animal manure from the garden & 1 & -1 \\
\hline Garden waste & 1 & -1 \\
\hline Compost from the garden & 1 & -1 \\
\hline Newspaper & 1 & -1 \\
\hline \multicolumn{3}{|l|}{ Animals in the garden? } \\
\hline None & -1 & 1 \\
\hline Chickens & 1 & -1 \\
\hline Bees & 1 & -1 \\
\hline
\end{tabular}




\begin{tabular}{|c|c|c|}
\hline Worms & 1 & -1 \\
\hline Other & 1 & 0 \\
\hline \multicolumn{3}{|l|}{ Water conservation strategy(s) used: } \\
\hline Relying on natural rainfall & 1 & -1 \\
\hline Rainwater tanks & 1 & -1 \\
\hline Mulching & 1 & -1 \\
\hline Low water-use plants & 1 & -1 \\
\hline Low water-use irrigation & 1 & -1 \\
\hline Swales & 1 & -1 \\
\hline \multicolumn{3}{|l|}{ Seedlings sourced from: } \\
\hline Supermarket & -1 & 1 \\
\hline Gardening outlet & -1 & 1 \\
\hline Organic seedlings store & 1 & -1 \\
\hline Local farmers markets & 1 & -1 \\
\hline GC/BNE Organic Growers Club Meetings & 1 & -1 \\
\hline Swap with members of garden & 1 & -1 \\
\hline Propagation & 1 & 0 \\
\hline \multicolumn{3}{|l|}{ Seed sourced from: } \\
\hline Supermarket & -1 & 1 \\
\hline Gardening outlet & -1 & 1 \\
\hline Organic seed store & 1 & -1 \\
\hline GC/BNE Organic Growers Club Meetings & 1 & -1 \\
\hline Seed saving & 1 & -1 \\
\hline Swap in between members of garden & 1 & -1 \\
\hline NSCF/local farmers markets & 1 & -1 \\
\hline \multicolumn{3}{|l|}{ Seed sourcing policy required using: } \\
\hline Only certified organic & 1 & 0 \\
\hline Only heirloom & 1 & 0 \\
\hline Trying to use organic & 1 & 0 \\
\hline Trying to use heirloom & 1 & 0 \\
\hline Free & -1 & 1 \\
\hline
\end{tabular}

\section{Results}

Characteristics of the community gardens

Collectively the 50 gardens occupied $57,000 \mathrm{~m}^{2}$ of land, ranging from $6 \mathrm{~m}^{2}$ to 19,200 $\mathrm{m}^{2}$ and averaging $1139 \pm 384 \mathrm{~m}^{2}$, with the Northey Street City Farm in Brisbane was by far the largest at 19,200 $\mathrm{m}^{2}$ and the oldest, established in 1974. Excluding this garden, garden sizes 
ranged from $6 \mathrm{~m}^{2}$ to $3080 \mathrm{~m}^{2}$, averaging $770 \pm 111 \mathrm{~m}^{2}$. Most of the community gardens were recently established, with the majority developed since 2007 (Figure 2). Most of the land on which gardens were located was publicly owned by state or local government (88\%), with the remainder on privately owned land. All the school gardens, and most of the non-profit (NPO) gardens did not have private plots (plots allocated to individuals), instead gardeners shared both the labour and produce from all plots within the gardens. For those gardens with private plots, the number of plots per garden ranged from 12 to 46; most of these gardens had a waiting list as private plots were in high demand.

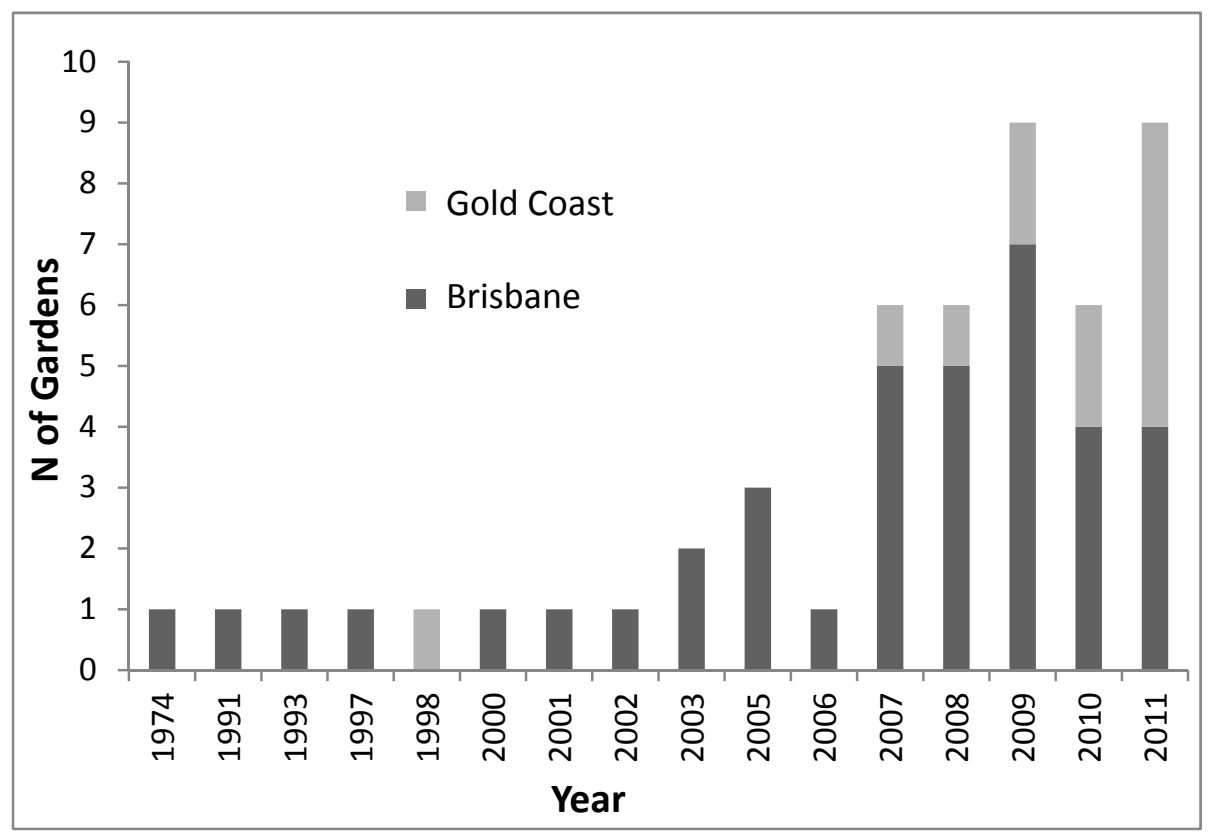

Figure 2 Year of establishment of community gardens in Brisbane and the Gold Coast $(n=50)$.

Motivations for developing gardens

Garden managers reported that the most common motivations underpinning the development of community gardens in the study area were education (50\%), community building (50\%), and environmental sustainability (34\%). They also mentioned increased health (18\%), 
relaxation/leisure space (12\%), living skills ${ }^{\text {iv }}(10 \%)$, contact with nature (6\%) and exercise (6\%). Other motivations included: to produce food locally, for urban renewal, to grow food for needy people, and for spirituality (Table 2). These results corroborate the findings of previous community garden studies.

\section{Cultural diversity of gardeners}

Gardens were surprisingly culturally diverse. Garden managers reported membership from: South East Asia (52\%), Southern and Central Asia (48\%), North East Asia (42\%), New Zealand (40\%), Pacific Islands (36\%), Australian Aboriginals (34\%), North West Europe (34\%), Africa (34\%), Middle East (30\%) and South East Europe (28\%). There were fewer gardens with members from Latin America (18\%), the Torres Strait Islands (18\%) and North America (8\%) (Table 2). School gardens were significantly more culturally diverse than nonprofit gardens (One-Way ANOVA, $\mathrm{F}=5.369 \mathrm{P}=0.025$ ). School gardens had students from up to fourteen different cultural backgrounds (average $6.4 \pm$ S.E. 0.8) while non-profit gardens had members from up to nine different cultural backgrounds (4.3 \pm 0.5$)$. More specifically, school gardens were more likely to have members who had Aboriginal and Torres Strait Islander backgrounds than non-profit gardens (Chi-squared test, $\mathrm{P}=0.007$ ). Although the gardens in the study area generally had higher cultural diversity than has been reported in the literature, this did not appear to influence gardening practices. 
Table 2 General characteristics of 50 community gardens surveyed across Brisbane and the Gold Coast.

\begin{tabular}{|c|c|c|c|c|c|}
\hline Variables & $\begin{array}{c}\text { Total } \\
(n=50)\end{array}$ & $\begin{array}{l}\text { School } \\
(n=23)\end{array}$ & $\begin{array}{c}\text { NPO } \\
(n=27)\end{array}$ & $\begin{array}{l}\text { Perma } \\
(n=21)\end{array}$ & $\begin{array}{c}\text { Non-perma } \\
(n=29)\end{array}$ \\
\hline \multicolumn{6}{|l|}{ Garden Location } \\
\hline Brisbane & 38 & 17 & 21 & 15 & 23 \\
\hline Gold Coast & 12 & 6 & 6 & 6 & 6 \\
\hline \multicolumn{6}{|l|}{ Type of Organisation } \\
\hline Non Profit & 27 & & & 12 & 15 \\
\hline School & 23 & & & 9 & 14 \\
\hline \multicolumn{6}{|l|}{ Land Ownership } \\
\hline Public & 42 & 22 & 20 & 17 & 25 \\
\hline Private & 8 & 1 & 7 & 4 & 4 \\
\hline \multicolumn{6}{|l|}{ Individual Plots } \\
\hline No & 39 & 23 & 16 & 9 & 7 \\
\hline Yes & 11 & & 11 & 3 & 8 \\
\hline \multicolumn{6}{|l|}{ Waiting list? } \\
\hline No & 20 & $*$ & 20 & 9 & 11 \\
\hline Yes & 7 & $*$ & 7 & 3 & 4 \\
\hline \multicolumn{6}{|l|}{ Motivation(s) } \\
\hline Education/research & 25 & 20 & 5 & 9 & 6 \\
\hline Community building & 25 & 5 & 20 & 13 & 12 \\
\hline Other & 19 & 9 & 10 & 8 & 11 \\
\hline Environmental sustainability & 17 & 8 & 9 & 8 & 9 \\
\hline $\begin{array}{l}\text { Health } \\
\text { Stephanie Alexander Kitchen }\end{array}$ & 9 & 7 & 2 & 4 & 5 \\
\hline Garden Foundation grant & 7 & 7 & & 5 & 2 \\
\hline Relax/leisure & 6 & 1 & 5 & 4 & 2 \\
\hline Living skills & 5 & 2 & 3 & 0 & 5 \\
\hline Contact w nature & 3 & 2 & 1 & 3 & \\
\hline Exercise & 3 & 1 & 2 & 2 & 1 \\
\hline Save/make money & 2 & & 2 & 1 & 1 \\
\hline Culture & 1 & & 1 & & 1 \\
\hline \multicolumn{6}{|l|}{ Crime reduction } \\
\hline \multicolumn{6}{|l|}{ Gardening philosophy** } \\
\hline Non-permaculture & 29 & 14 & 15 & & \\
\hline Permaculture & 21 & 9 & 12 & & \\
\hline $\begin{array}{l}\text { Cultural backgrounds of membe } \\
\text { Number of different cultural } \\
\text { backgrounds }\end{array}$ & $1-14$ & $1-14$ & $1-9$ & $1-13$ & $1-14$ \\
\hline \multicolumn{6}{|l|}{ Australian } \\
\hline Aboriginal & 17 & 14 & 3 & 7 & 10 \\
\hline Torres Strait Islander & 9 & 7 & 2 & 4 & 5 \\
\hline Other Australians & 50 & 23 & 27 & 21 & 29 \\
\hline South East Asian & 26 & 13 & 13 & 7 & 19 \\
\hline Southern and Central Asian & 24 & 12 & 12 & 9 & 15 \\
\hline
\end{tabular}




\begin{tabular}{|c|c|c|c|c|c|}
\hline North East Asian & 21 & 11 & 10 & 6 & 15 \\
\hline Maori & 20 & 14 & 6 & 7 & 13 \\
\hline Pacific Islander & 18 & 11 & 7 & 5 & 13 \\
\hline African & 17 & 10 & 7 & 5 & 12 \\
\hline North West European & 17 & 7 & 10 & 6 & 11 \\
\hline Middle Eastern & 15 & 9 & 6 & 3 & 12 \\
\hline South Eastern European & 14 & 8 & 6 & 7 & 7 \\
\hline Latin American & 9 & 5 & 4 & 5 & 4 \\
\hline North American & 4 & 2 & 2 & 1 & 3 \\
\hline \multicolumn{6}{|l|}{ Facilities } \\
\hline Compost & 46 & 21 & 25 & 19 & 27 \\
\hline Communal tool shed & 45 & 20 & 25 & 20 & 25 \\
\hline Rainwater tanks & 44 & 20 & 24 & 18 & 26 \\
\hline Toilets & 40 & 19 & 21 & 16 & 24 \\
\hline Worm farm & 37 & 20 & 17 & 17 & 20 \\
\hline Wheel chair access & 33 & 12 & 21 & 14 & 19 \\
\hline Kitchen & 29 & 15 & 14 & 14 & 15 \\
\hline Meeting room/shed & 28 & 16 & 12 & 14 & 14 \\
\hline Nursery/propagation area & 26 & 13 & 13 & 18 & 8 \\
\hline Library with gardening books & 25 & 16 & 9 & 9 & 16 \\
\hline Barbeque & 25 & 10 & 15 & 8 & 17 \\
\hline Play area for children & 25 & 17 & 8 & 9 & 16 \\
\hline Fence & 20 & 11 & 9 & 7 & 13 \\
\hline Public art & 20 & 8 & 12 & 8 & 12 \\
\hline Educational signs & 18 & 7 & 11 & 10 & 8 \\
\hline Solar panels & 13 & 9 & 4 & 5 & 8 \\
\hline Garden materials storage shed & 9 & 2 & 7 & 4 & 5 \\
\hline Cob oven & 6 & 2 & 4 & 5 & 1 \\
\hline
\end{tabular}

\section{Garden facilities and practices}

Gardens tended to have more facilities than has been previously reported in the literature. Most gardens had compost bin(s) (92\%), a communal tool shed (90\%), toilets (80\%) and worm farm(s) (74\%). Other facilities included wheel chair access (66\%), a kitchen (58\%), meeting areas (56\%), and a nursery or propagation area (52\%). Half of the gardens had libraries with gardening books, play areas for children and barbeques. Some had fences (40\%), public art (40\%), and educational signs (36\%). Fewer featured a garden materials 
storage shed (18\%) or a cob oven (12\%). Most had rainwater tanks (88\%), although 64\% still used mains water while only $4 \%$ used grey water. All but three gardens had electricity on-site and all but four used mains power, while 26\% also used solar panels (Table 2). The only significant difference in gardening facilities between school and not for profit gardens was for the presence of nurseries and/or propagation areas for seedlings; more school gardens (57\%) had nurseries or propagation areas than non-profit gardens (48\%), (Chi-square test, $\mathrm{P}=$ 0.017).

Nearly all gardens (90\%) initially reported being chemical-free or organic, although two of these gardens later reported using synthetic fertilisers or pesticides for soil improvement and pest control. After cross validation, $86 \%$ of the gardens were actually chemical-free or organic. The main soil improvement methods were: homemade compost (90\%); commercial organic fertilizers (80\%) such as mushroom compost, blood and bone, fish emulsion, rock dust, etc.; and worm castings (72\%). Other methods for soil improvement included: growing 'green manure'v (64\%), locally sourced animal manure (62\%), and homemade fertilizers (54\%). Only three garden managers (6\%) reported using commercial synthetic fertilisers and in another three gardens nothing was explicitly done to improve soil nutrients. Common weed, pest and disease control methods included companion planting (72\%), planting in season and climate (68\%), attracting beneficial insects (58\%), and crop rotation (56\%). Other methods included: maintaining healthy soil (50\%), using highly diverse plant species (44\%), homemade natural pesticides (42\%), keeping animals (24\%), manually pulling weeds (24\%), and planting disease resistant plants (24\%). Few gardens used commercial synthetic pesticides, fungicides and/or herbicides (10\%). 
Three quarters (76\%) of the gardens made their own soil (e.g. adding compost and other materials). Two thirds (66\%) sourced soil from landscape yards by either buying it or having it donated, whilst $42 \%$ did both. Most gardens (78\%) used commercial mulch (e.g. sugar cane mulch), while half used garden waste; only $6 \%$ of gardens did not use any mulch. Animals were common in gardens, including: worm farms (72\%), chicken runs (34\%), and bee hives (16\%). Water conservation strategies included: rain water tanks (84\%), mulching (78\%) and raised beds (60\%). Some gardens also used natural rainfall (42\%), swales (20\%), low water-use irrigation (12\%), and low water-use plants (10\%). Very few gardens (6\%) used other systems (e.g. aquaponics or recycling grey water). Most gardens (88\%) ran educational workshops, including workshops on permaculture principles, seed saving, composting, no-dig gardening, mulching, propagating, and medicinal herbs (see Table 3). There were no significant differences in gardening practices between the school and non-profit gardens.

Table 3 Gardening practices of 50 community gardens surveyed across Brisbane and the Gold Coast.

\begin{tabular}{|c|c|c|c|c|c|}
\hline Variables & $\begin{array}{c}\text { Total } \\
(n=50)\end{array}$ & $\begin{array}{l}\text { School } \\
(n=23)\end{array}$ & $\begin{array}{c}\text { NPO } \\
(n=27)\end{array}$ & $\begin{array}{l}\text { Perma } \\
(n=21)\end{array}$ & $\begin{array}{c}\text { Non-perma } \\
(n=29) \\
\end{array}$ \\
\hline \multicolumn{6}{|l|}{ Use of chemicals: } \\
\hline Organic/chemical-free & 43 & 20 & 23 & 21 & 22 \\
\hline Conventional/use of chemicals & 7 & 3 & 4 & 0 & 7 \\
\hline \multicolumn{6}{|l|}{ Soil sourcing: } \\
\hline Build own soil & 38 & 17 & 21 & 19 & 19 \\
\hline From landscape yards & 33 & 19 & 14 & 12 & 21 \\
\hline \multicolumn{6}{|l|}{ Soil improved using: } \\
\hline Homemade compost & 45 & 20 & 25 & 20 & 25 \\
\hline Commercial organic fertilizers & 40 & 20 & 20 & 17 & 23 \\
\hline Worm castings & 36 & 18 & 18 & 16 & 20 \\
\hline Locally grown green manure & 32 & 14 & 18 & 18 & 14 \\
\hline Locally sourced animal manure & 31 & 11 & 20 & 16 & 15 \\
\hline Homemade fertilizers & 27 & 10 & 17 & 17 & 10 \\
\hline Soil is left as is & 3 & 2 & 1 & 1 & 2 \\
\hline Commercial synthetic fertilizers & 3 & 2 & 1 & & 3 \\
\hline \multicolumn{6}{|c|}{ Weeds, pests, diseases controlled by using: } \\
\hline Companion planting & 36 & 15 & 21 & 20 & 16 \\
\hline
\end{tabular}




\begin{tabular}{|c|c|c|c|c|c|}
\hline Planting in season/climate & 34 & 16 & 18 & 17 & 17 \\
\hline $\begin{array}{l}\text { Specific planting to attract beneficial } \\
\text { insects }\end{array}$ & 29 & 14 & 15 & 16 & 13 \\
\hline Crop rotating & 28 & 14 & 14 & 15 & 13 \\
\hline Maintaining healthy soil & 25 & 10 & 15 & 15 & 10 \\
\hline Using highly diverse plant species & 22 & 8 & 14 & 14 & 8 \\
\hline Homemade natural pesticides & 21 & 7 & 14 & 8 & 13 \\
\hline Keeping animals & 12 & 9 & 3 & 7 & 5 \\
\hline Planting disease resistant varieties & 12 & 6 & 6 & 6 & 6 \\
\hline Pull out weeds & 12 & 8 & 4 & 3 & 9 \\
\hline Soap & 8 & 3 & 5 & 3 & 5 \\
\hline Commercial synthetic pesticides & 5 & 3 & 2 & & 5 \\
\hline \multicolumn{6}{|l|}{ Type of mulch used: } \\
\hline $\begin{array}{l}\text { Commercial mulch } \\
\text { Straw, lucerne hay, green manure from }\end{array}$ & 39 & 18 & 21 & 17 & 22 \\
\hline $\begin{array}{l}\text { Straw, lucerne hay, green manure from } \\
\text { garden }\end{array}$ & 26 & 13 & 13 & 15 & 11 \\
\hline Garden waste & 25 & 10 & 15 & 12 & 13 \\
\hline Newspaper & 15 & 8 & 7 & 7 & 8 \\
\hline Compost from the garden & 14 & 7 & 7 & 8 & 6 \\
\hline Don't use mulch & 3 & 1 & 2 & & 3 \\
\hline Animal manure from the garden & 3 & 3 & & 2 & 1 \\
\hline Commercial animal manure & 2 & 1 & 1 & 1 & 1 \\
\hline Plastic & 1 & 1 & & & 1 \\
\hline \multicolumn{6}{|l|}{ Animals in the garden? } \\
\hline Worms & 36 & 19 & 17 & 16 & 20 \\
\hline Chickens & 17 & 13 & 4 & 8 & 9 \\
\hline None & 12 & 3 & 9 & 4 & 8 \\
\hline Bees & 8 & 4 & 4 & 5 & 3 \\
\hline Other & 3 & 2 & 1 & & 3 \\
\hline \multicolumn{6}{|l|}{ Water conservation strategy(s) used: } \\
\hline Rainwater tanks & 42 & 19 & 23 & 16 & 26 \\
\hline Mulching & 39 & 17 & 22 & 17 & 22 \\
\hline Raised beds & 30 & 14 & 16 & 15 & 15 \\
\hline Relying on natural rainfall & 21 & 9 & 12 & 10 & 11 \\
\hline Others & 15 & 4 & 11 & 6 & 9 \\
\hline Swales & 10 & 3 & 7 & 6 & 4 \\
\hline Low water-use irrigation & 6 & 4 & 2 & 4 & 2 \\
\hline Low water-use plants & 5 & 3 & 2 & 2 & 3 \\
\hline \multicolumn{6}{|l|}{ Gardening training/workshops: } \\
\hline Yes & 44 & 22 & 22 & 20 & 24 \\
\hline No & 6 & 1 & 5 & 1 & 5 \\
\hline
\end{tabular}

Almost half of the garden managers (42\%) reported permaculture as the overarching practice/philosophy, which in turn affected other gardening practices (Table 3). Gardens with 
permaculture-type practices had significantly higher permaculture index than other gardens (10.3 \pm 1.7 vs. $-7.5 \pm 2.2$; One-Way ANOVA, $\mathrm{F}=33.416, \mathrm{P}<0.001)$ (Figure 3). More permaculture gardens used homemade fertilizers to improve soil quality (Chi-Squared test, $\mathrm{P}$ $=0.027)$ and plant diversity as way of limiting weeds, pests and diseases $(\mathrm{P}=0.040)$, than non-permaculture gardens. Unlike the international literature, we found no statistically significant differences in the size and age of the gardens, or motivations to establish them.

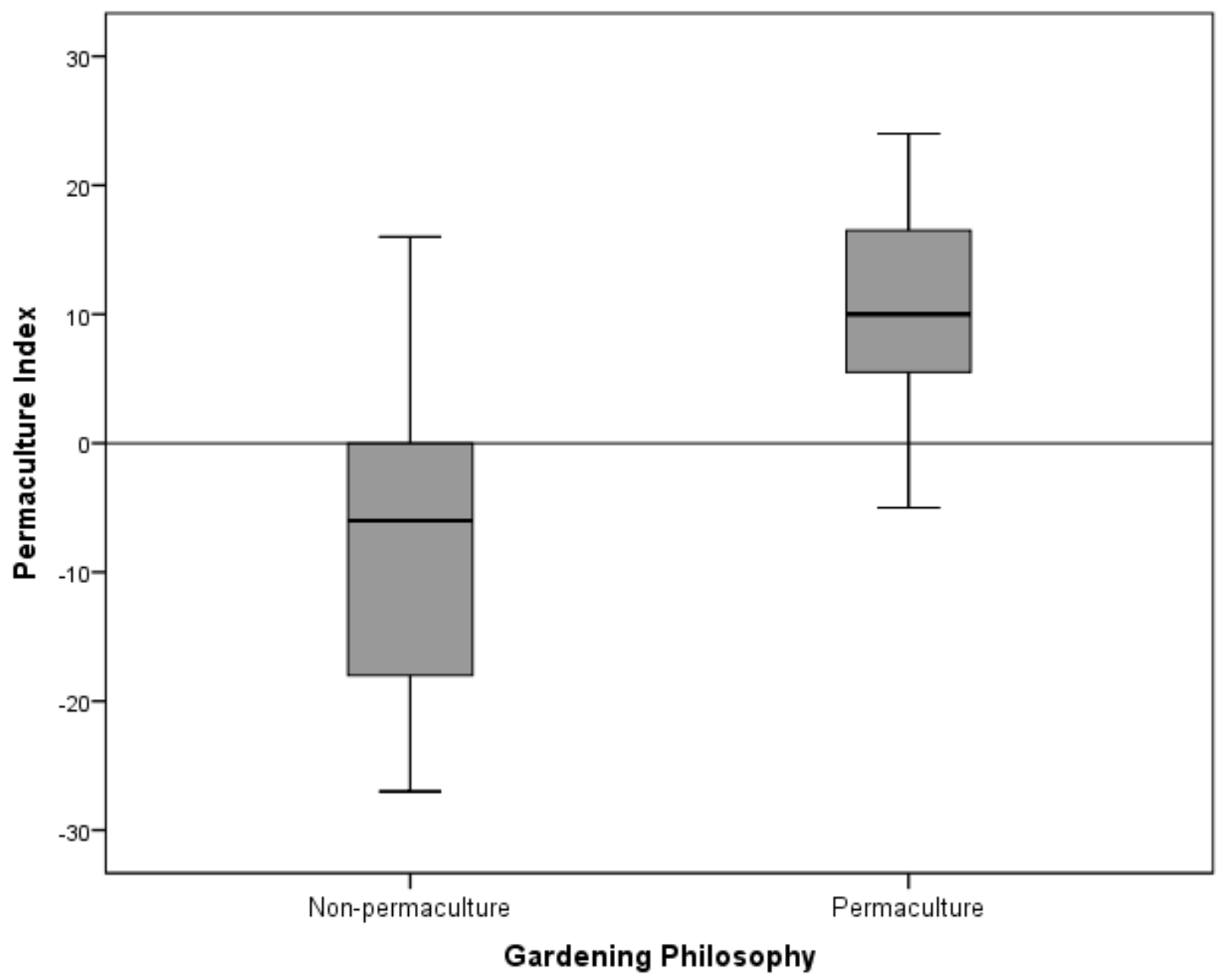

Figure 3 Average permaculture index for permaculture versus non permaculture gardens. Dark line in the middle of each box indicates the median of the index, the bottom of the box indicates the $25^{\text {th }}$ percentile, the top of the box indicates $75^{\text {th }}$ percentile, and T bars extending from the boxes indicate minimum and maximum values. 


\section{Discussion}

This study had five related aims; it sought to better understand: (i) the characteristics of community gardens including motivations, structures and funding; (ii) how people garden (garden practice); (iii) why they garden that way; (iv) whether their practices are environmental sustainable; and (v) how knowledge about these gardens can better inform land use policy and decisions about community garden development.

\section{Characteristics of gardens}

We found that community gardens are widespread in Brisbane and the Gold Coast, with 53 gardens operating (as of June 2011). Of the 50 gardens surveyed, most were new, with 30 gardens (60\%) established after 2007 (see Figure 2). This reflects national and international trends in the popularity of community gardens, with a large number of gardens recently established (Somerset et al. 2005, Turner et al. 2011).

The organisation managing a garden appears to play a strong role in both the success of the garden and in gardening practices (Guitart et al. 2012). Internationally, researchers have found that organisations that run community gardens include hospitals, jails and commercial organisations (Pudup 2008, Turner et al. 2011). We found that Brisbane and Gold Coast community gardens were either run by schools (46\%) or non-profit organisations. We also found that the nature of the organisation affected the motivations for establishing and operating the community gardens. School-based community gardens in Brisbane and Gold Coast cities were similar to school gardens elsewhere; they are used to teach science, environmental studies and nutrition and, in many instances, are part of the school curriculum (Blair 2009, Somerset et al. 2005). 
Non-profit gardens in our study area, on the other hand, were mainly motivated by community building, which is also the most commonly cited motivation in the international literature (besides fresh food consumption) (Glover et al. 2005, Hancock 2001, SaldivarTanaka and Krasny 2004). Corroborating the literature, other common motivations we found included: ‘environmental sustainability’ (DeKay 1997, Ferris et al. 2001, Holland 2004, Irvine et al. 1999, Stocker and Barnett 1998, Wakefield et al. 2007, Wills et al. 2009); improving health (Armstrong 2000a, Kingsley et al. 2009, Milligan et al. 2004, Somerset et al. 2005); and enhancing social inclusion and preserving cultural practices (Armstrong 2000b, Irazabal and Punja 2009).

In contrast to the literature, we found greater cultural diversity in school gardens compared to non-profit gardens in Brisbane and the Gold Coast. This may reflect the nature of many Australian schools, which are ethno-racially diverse (Den Brok and Levy 2005, Mansouri and Jenkins 2010), or more likely could reflect the greater knowledge of school garden managers about the ethno-racial composition of child-gardeners compared to that of managers of non-profit gardens. Contrary to our expectations, and unlike findings reported in the international literature, the differences in motivation and cultural diversity between school and non-profit community gardens did not appear to affect garden practices or plants grown.

International research has also found that some community gardens fulfil both subsistence and livelihood functions, enabling gardeners to sell their produce for profit, such as gardens in: Khayelitsha (Southern Africa) (Karaan and Mohamed 1998); Belem (Brazil) (Madaleno 2000); and in the Philippines, Zambia and Mexico (Wade 1987). This was not a common practice for Brisbane or Gold Coast community gardens. One explanation for this difference is that socio-economic disadvantage in Australia tends to be concentrated in the middle to outer ring suburbs (Leslie et al. 2007). Community gardens in our study area were 
disproportionately located in inner-ring suburbs, areas dominated by wealthier people, and they appear to serve social, recreational and educational functions, and provide opportunities to encounter nature.

\section{Gardening practices and environmental sustainability}

Many of the community gardens we assessed engaged in gardening practices that are ecologically beneficial. Most gardens (90\%) did not use synthetic chemicals for pest control (e.g. herbicides, pesticides and fungicides) or for soil improvement (94\%); instead they used companion planting, manual removal, compost bins and worm farms (among other practices). Almost all of the gardens had a rainwater tank but only two gardens recycled waste water. Nearly all of the gardens also engaged in practices supporting the dynamic conservation of heritage plants including seed saving, swapping seeds/plants between members, and using organic seed/seedling providers. However, only a few gardens generated their own electricity or used water-conserving irrigation systems.

Surprisingly, almost half of all the gardens located in Brisbane and Gold Coast cities were strongly influenced by permaculture. This may be due to an accident of geography, with the permaculture concept originating in northern New South Wales, which is close to Brisbane and Gold Coast cities (Holmgren 2002, Veteto and Lockyer 2008). In the three decades since the permaculture concept was developed, it has spread to over 100 countries. While many permaculture practices are environmentally sustainable, permaculture has been critiqued for its potential to propagate environmental weeds (e.g. Leucaena and Popcorn cassia which are recommended by permaculturists for nitrogen fixing but are widely considered to be weeds) (Holmgren 1997). In the current study, some permaculture and nonpermaculture gardens grew plants which can become weeds (e.g. yarrow, blackberry, passion 
fruit, amaranth and pennywort) (Kleinschmidt et al. 1996). The extent to which community gardens may be unintentionally contributing to the spread of weedy species should be addressed by future research.

We acknowledge that many of the above-mentioned beneficial practices are a proxy for measuring the environmental impact of the gardens. Given that we found significant regional variations in community gardening practices, further research is required to empirically evaluate environmental impacts. Potential environmental impacts include: weed proliferation, nutrient export, air pollution, and off-site chemical impacts. To better evaluate the environmental impacts of community gardens more information is needed about the flow of nutrients out of the gardens into surface and ground water, the energy used in the gardens, the travel behaviour of the gardeners, ecosystem service benefits of the gardens (e.g. storm-water attenuation, pollution interception, carbon sequestration, dust suppression, and temperature moderation), how the gardens impact wildlife, and how the gardens might contribute to agrobiodiversity.

Implications for environmental planning, land use policy, and decision-making

A benefit of producing food locally is that it provides a source of food close to where people live (Holland 2004, Twiss et al. 2003), making cities less reliant on imported food, with flow on environmental benefits (e.g. reduced carbon emissions and pollution from transport, healthier populations) (Satterthwaite et al. 2010). ${ }^{\mathrm{vi}}$ International studies have found that many community gardens attract some form of government support, presumably for the social and environmental benefits they are seen to provide (Armstrong 2000b, Voicu and Been 2008). Access to public land is notable subsidy. For instance, $96 \%$ of community gardens within US cities like New York (Saldivar-Tanaka and Krasny 2004, Staeheli et al. 2002), are located on 
publicly owned land (American Community Gardening Association 1998). Community gardens are also located on publicly owned land in the United Kingdom (Howe and Wheeler 1999), Sweden (Klein 1993), South Africa (Wills et al. 2009), Canada (Irvine et al. 1999) and Australia - in Sydney, New South Wales (Corkery 2004) and Melbourne, Victoria (Freestone and Nichols 2004).

We found that community gardens in Brisbane and Gold Coast cities are also supported by government - at the local and state level, primarily through land provision. However, tacit support also occurs through policies that encourage the establishment of community gardens. We found that local governments directly supported the non-profit gardens through information, start-up assistance, and through some funding. State Government supported school gardens through the Department of Education, including teacher training and covering the cost of materials. But is this support well-placed? It is reasonable to allocate public land exclusively for community gardens when urban greenspace is in high demand? These are important questions for environmental planners.

One of the factors driving community garden development in the study area is a government policy of 'urban consolidation' (also known as urban containment or smart growth) (Byrne et al. 2010). This environmentally-oriented State government policy implements growth management objectives by fostering the development of multi-unit, multi-storey apartment complexes on land previously occupied by single-family housing - as a way to accommodate more people within the existing urban footprint (Searle 2010). It has resulted in a decrease in residential lot sizes (from over $1,000 \mathrm{~m}^{2}$ in the 1960 s to an average lot size now of around half that). But an unintended consequence has been a steady attrition of private urban green-space, especially backyards (Byrne et al. 2010, Hall 2010). Public open space is consequently coming under increasing pressure, and community gardens to 
some extent function as a surrogate for lost private greenspace. However, some international research now suggests that home gardens could be more agriculturally productive than community gardens (Taylor and Lovell 2012), suggesting community gardens are no substitute for lost backyards.

Against this policy backdrop, it is highly important for environmental planners to understand the environmental impacts of community gardens. Community gardens are often given a privileged status due to their reputed social and environmental benefits; they outcompete other potential uses of urban greenspace for exclusive access (Tan and Neo 2009). Do community gardens live up to their environmental reputation and can exclusive access be justified? We would like to think so. In Queensland we found that most community gardens appear to be environmentally beneficial and warrant the support they receive. Whether this is the case elsewhere, remains to be seen.

Planners also need to consider the importance of stable tenure for nurturing community gardens, because such gardens require a constant investment of time and energy from their users and take time to reach their full potential (e.g. when fruit trees mature). One of the worst outcomes for community investment in urban agricultural spaces like community gardens is for such spaces to be lost to other uses (Armstrong 2000b, Pudup 2008). Indeed, Lawson (2004: 151) argues that the relationship between planners and community gardens has historically been ambivalent; while community gardens are 'praised and supported as local action to serve environmental ...objectives, they are [also] perceived as opportunistic and temporary...largely ignored in long-range planning'. This can create cynicism and resentment, and may ultimately undo years or even decades of environmental stewardship as international studies on planning's failure to protect community gardens have found (Irazabal and Punja 2009, Saldivar-Tanaka and Krasny 2004, Schmelzkopf 2002, Staeheli et 
al. 2002, Wakefield et al. 2007). Some scholars have even suggested that community gardens could be considered a type of abrogation of environmental responsibilities by the neoliberal state (McClintock 2013). Clearly we need a more comprehensive assessment of the environmental benefits and impacts of community gardens together with a better appreciation of their needs, such as: building setbacks, solar access, noise, viable garden size, optimal facilities, and appropriate methods of waste management, power supply, and water conservation (DeKay 1997).

\section{Conclusion}

Ultimately, the long-term viability of urban food systems is dependent not only upon social factors, such as motivations and governance, but also upon environmental factors, such as the type of gardening practices and the types of plants grown (Kortright and Wakefield 2009). Currently policy makers and decision makers appear to take the environmental credentials of community gardens as a given. In this paper we have argued that assessing the gardening practices used in community gardens is vitally important because internationally, our understanding of how community gardens might impact the environment is currently very limited. Although several studies have suggested that 'environmental sustainability' is an important motivation for developing community gardens (DeKay 1997, Ferris et al. 2001, Holland 2004, Irvine et al. 1999, Stocker and Barnett 1998, Wakefield et al. 2007, Wills et al. 2009), decision-makers currently lack empirical evidence to substantiate claims about environmental benefit. Until now, no study has systematically assessed how gardening practices potentially shape the environmental impacts of community gardens.

Our study examined community gardens in Brisbane and Gold Coast cities, Australia to ascertain their garden characteristics, agricultural practices, and sustainability. This included 
developing a permaculture index to assess whether gardening philosophy matches gardening practices. We found that just under half of the gardens used permaculture gardening practices and many of the non-permaculture gardens used some more environmentally beneficial practices. In other words, most gardens in the study area appear to be environmentally beneficial.

This is important because community gardens in South East Queensland are undergoing a rapid expansion. Over half of the community gardens in Gold Coast City have been established since 2007. Potential drivers of this rapid growth include: supportive government policy; generous support from non-profit organisations such as the Kitchen Garden Foundation (Kitchen Garden Foundation 2010) and Biological Farmers of Australia (Biological Farmers of Australia 2010); growing awareness within the community about the health impacts of sedentary lifestyles, and; rising concerns about food security. The perceived environmental benefits of community gardens also appear to underwrite government policy supporting their establishment.

We found that while many community gardens in the study area provide an environmental/ecological function that has seldom been reported in previous studies, not all community gardens we assessed were environmentally benign. Although permaculture-based gardens did not use synthetic pesticides and herbicides, sourced seeds sustainably, used water efficiently, and built up soil fertility, some gardens sourced seeds from commercial providers, used synthetic chemicals, imported nutrients, and potentially harboured weeds.

However, we were not able to fully assess the environmental impacts of gardens in the study area due to limited time and resources, and this was never our intention. Future research should seek to quantify the extent of the ecological benefits of community gardens, both within and outside Australia. This might be done by assessing their ecosystem services 
or evaluating how these gardens contribute to agro-biodiversity. Future research should also assess whether community gardens are detracting from, or complementing, other potential uses of the publicly-owned sites that they occupy, given that increasing competition for access to urban green-space is a problem in rapidly growing in cities across the globe. It would also be beneficial to quantify the volume of garden produce generated by community gardens, to test their efficacy as an alternative model for urban food production. And it would be beneficial to rigorously assess the environmental impacts of the various types of gardening practices we have identified here. This could include studies investigating soil contamination from pesticides and herbicides, run-off from stormwater, nutrient export, species abundance and the like.

Our study has provided a solid foundation for researchers to begin to answer some of these compelling questions. We have developed a unique index for assessing gardening practices, which we have demonstrated is capable of being applied for assessing community gardens in other high-growth areas. There is considerable potential to compare our findings to gardens in the Shanghai-Hangzhou conurbation in China, the Boston-Washington corridor in the United States or with gardens in Southern California, for example. What is clear from our study is that if growing numbers community gardens employ 'sustainable gardening practices' and have lower environmental impacts, the future of urban agriculture looks promising. 


\section{References}

Altieri, M. A., Companioni, N., Cañizares, K., Murphy, C., Rosset, P., Bourque, M. and Nicholls, C. I. 1999. The greening of the "barrios": Urban agriculture for food security in Cuba. Agriculture and Human Values, 16(2), 131-140.

American Community Gardening Association, 1998. National Community Gardening Survey: 1996, Philadelphia [online]. Available from:

http://www.communitygarden.org/docs/learn/cgsurvey96part1.pdf. [Accessed $25 / 9 / 2012$

Armstrong, D. 2000a. A community diabetes education and gardening project to improve diabetes care in a Northwest American Indian tribe. The Diabetes Educator, 26(1), 113-120.

Armstrong, D. 2000b. A survey of community gardens in upstate New York: implications for health promotion and community development. Health and Place, 6(4), 319-327.

Baker, L. 2004. Tending cultural landscapes and food citizenship in Toronto's community gardens. Geographical Review, 94(3), 305-325.

Barthel, S., Parker, J. and Ernstson, H. 2013. Food and green space in cities: A resilience lens on gardens and urban environmental movements. Urban Studies, doi: $10.1177 / 0042098012472744$

Bartling, H. 2012. A chicken ain't nothin'but a bird: local food production and the politics of land-use change. Local Environment, 17(1), 23-34.

Biological Farmers of Australia, 2010. BFA Organic School Gardens Program, Chermside [online]. Available from: http://www.organicschools.com.au [Accessed 12/12/2010.

Blair, D. 2009. The child in the garden: An evaluative review of the benefits of school gardening. The Journal of Environmental Education, 40(2), 15-38. 
Byrne, J., Sipe, N. and Searle, G. 2010. Green around the gills? The challenge of density for urban greenspace planning in SEQ. Australian Planner, 47(3), 162-177.

Campbell, M. 2004. Building a common table: The role for planning in community food systems. Journal of Planning Education and Research, (23), 341-355.

Clavin, A. A. 2011. Realising ecological sustainability in community gardens: a capability approach. Local Environment, 16(10), 945-962.

Clayton, S. 2007. Domesticated nature: Motivations for gardening and perceptions of environmental impact. Journal of environmental psychology, 27(3), 215-224.

Clement, M. 2010. Urbanization and the natural environment: An environmental sociological review and synthesis. Organization and Environment, 23(3), 291.

Cone, C. A. and Myhre, A. 2000. Community-supported agriculture: A sustainable alternative to industrial agriculture? Human Organization, 59(2), 187-197.

Corkery, L. 2004. Community gardens as a platform for education for sustainability. Australian Journal of Environmental Education, 20(1), 61-75.

Corlett, J., Dean, E. and Grivetti, L. 2003. Hmong gardens: Botanical diversity in an urban setting. Economic Botany, 57(3), 365-379.

Corrigan, M. P. 2011. Growing what you eat: Developing community gardens in Baltimore, Maryland. Applied Geography, 31(4), 1232-1241.

Deelstra, T. and Girardet, H., 1999. Urban agriculture and sustainable cities. Thematic Paper 2. Growing Cities Growing Food: Urban Agriculture on the Policy Agenda: A Reader on Urban Agriculture. Resource Centre on Urban Agriculture and Forestry.

DeKay, M. 1997. The implications of community gardening for land use and density. Journal of Architectural and Planning Research, 14(2), 126-149.

Den Brok, P. and Levy, J. 2005. Teacher-student relationships in multicultural classes: Reviewing the past, preparing the future. International Journal of Educational Research, 43, 72-88. 
DeSilvey, C. 2003. Cultivated histories in a Scottish allotment garden. Cultural Geographies, 10(4), 442-468.

Endres, A. and Endres, J. 2009. Homeland security planning: what victory gardens and Fidel Castro can teach us in preparing for food crises in the United States. Food and Drug Law Journal, 64(2), 405.

Ferris, J., Norman, C. and Sempik, J. 2001. People, land and sustainability: Community gardens and the social dimension of sustainable development. Social Policy and Administration, 35(5), 559-568.

Fink, A., 2003. The Survey Kit: How to ask survey questions. Sage Publications, Thousand Oaks, California.

Freestone, R. and Nichols, D. 2004. Realising new leisure opportunities for old urban parks: the internal reserve in Australia. Landscape and urban planning, 68(1), 109-120.

Gaynor, A., 2006. Harvest of the suburbs: An environmental history of growing food in Australian cities. Crawley: University of Western Australia Press.

Glover, T., Shinew, K. and Parry, D. 2005. Association, sociability, and civic culture: The democratic effect of community gardening. Leisure Sciences, 27(1), 75-92.

Guitart, D., Pickering, C. and Byrne, J. 2012. Past results and future directions in urban community gardens research. Urban Forestry \& Urban Greening, 11(4), 364-373.

Hall, T. 2010. Goodbye to the backyard? - the minimisation of private open space in the Australian outer-suburban estate. Urban Policy and Research, 28(4), 411-433.

Hancock, T. 2001. People, partnerships and human progress: building community capital. Health Promotion International, 16(3), 275-280.

Harris, E. 2009. The role of community gardens in creating healthy communities. Australian Planner, 46(2), 24-27.

Heintzman, A. and Solomon, E., 2006. Feeding the future: From fat to famine, how to solve the world's food crises. Toronto: House of Anansi Press Inc. 
Holland, L. 2004. Diversity and connections in community gardens: a contribution to local sustainability. Local Environment, 9(3), 285-305.

Holmgren, D. 1997. Weeds or wild nature? Permaculture International Journal, 61.

Holmgren, D., 2002. Permaculture: Principles and pathways beyond sustainability. Hepburn: Chelsea Green Publishing Co.

Howe, J. and Wheeler, P. 1999. Urban food growing: The experience of two UK cities. Sustainable Development, 7(1), 13-24.

Irazabal, C. and Punja, A. 2009. Cultivating just planning and legal institutions: a critical assessment of the South Central Farm struggle in Los Angeles. Journal of Urban Affairs, 31(1), 1-23.

Irvine, S., Johnson, L. and Peters, K. 1999. Community gardens and sustainable land use planning: a case-study of the Alex Wilson Community Garden. Local Environment, 4(1), 33-46.

Jarosz, L. 2008. The city in the country: Growing alternative food networks in Metropolitan areas. Journal of Rural Studies, 24(3), 231-244.

Karaan, A. and Mohamed, N. 1998. The performance and support of food gardens in some townships of the Cape Metropolitan area: An evaluation of Abalimi Bezekhaya. Development Southern Africa, 15(1), 67-83.

King, C. A. 2008. Community resilience and contemporary agri-ecological systems: Reconnecting people and food, and people with people. Systems Research and Behavioral Science, 25(1), 111-124.

Kingsley, J., Townsend, M. and Henderson-Wilson, C. 2009. Cultivating health and wellbeing: members' perceptions of the health benefits of a Port Melbourne community garden. Leisure Studies, 28(2), 207-219.

Kitchen Garden Foundation, 2010. Stephanie Alexander Kitchen Garden Foundation [online]. Collingwood. Available from: www.kitchengardenfoundation.org.au [Accessed 2/10/2011. 
Klein, B. 1993. Fences, fertilizers, and foreigners: moral dilemmas in the Swedish cultural landscape. Journal of Folklore Research, 30(1), 45-59.

Kleinschmidt, H. E., Rankin, G. and Saul, M. A., 1996. Suburban weeds. 3rd ed. Brisbane: Queensland Deptartment of Primary Industries.

Kortright, R. and Wakefield, S. 2009. Edible backyards: a qualitative study of household food growing and its contributions to food security. Agriculture and Human Values, 1-15.

Kurtz, H. 2001. Differentiating multiple meanings of garden and community. Urban Geography, 22(7), 656-670.

Lautenschlager, L. and Smith, C. 2007. Beliefs, knowledge, and values held by inner-city youth about gardening, nutrition, and cooking. Agriculture and Human Values, 24(2), 245-258.

Lawson, L. 2004. The planner in the garden: A historical view into the relationship between planning and community gardens. Journal of Planning History, 3(2), 151-176.

Leslie, E., McCrea, R., Cerin, E. and Stimson, R. 2007. Regional variations in walking for different purposes: the South East Queensland quality of life study. Environment and Behavior, 39(4), 557-577.

Madaleno, I. 2000. Urban agriculture in Belém, Brazil. Cities, 17(1), 73-77.

Mansouri, F. and Jenkins, L. 2010. Schools as sites of race relations and intercultural tension. Australian journal of teacher education, 35(7), 8.

Martin, R. and Marsden, T. 1999. Food for urban spaces: The development of urban food production in England and Wales. International Planning Studies, 4(3), 389-412.

McClintock, N. 2013. Radical, reformist, and garden-variety neoliberal: coming to terms with urban agriculture's contradictions. Local Environment, (ahead-of-print), 1-25.

Milligan, C., Gatrell, A. and Bingley, A. 2004. Cultivating health: Therapeutic landscapes and older people in Northern England. Social Science and Medicine, 58(9), 17811793. 
Mollison, B., 1988. Permaculture: A designer's manual. Tyalgum: Tagari Publications.

Mollison, B., 1994. Introduction to Permaculture. 2nd ed. Tyalgum: Tagari Publications.

Moreno-Black, G., Somnasang, P. and Thamathawan, S. 1996. Cultivating continuity and creating change: women's home garden practices in northeastern Thailand. Agriculture and Human Values, 13(3), 3-11.

Morrow, R., 2006. Earth User's Guide to Permaculture. 2nd ed. Hampshire: Permanent Publications.

Nettle, C., 2010. Community gardening: An annotated bibliography. Australian City Farms and Community Garden Network, 48.

Pack, C., 1919. The War Garden Victorious. Bedford, Ma.: Applewood Books.

Pearson, D. H. and Firth, C. 2012. Diversity in community gardens: Evidence from one region in the United Kingdom. Biological Agriculture \& Horticulture: An International Journal for Sustainable Production Systems, 28(3), 147-155.

Pudup, M. 2008. It takes a garden: Cultivating citizen-subjects in organized garden projects. Geoforum, 39(3), 1228-1240.

Queensland Government, 2009. South East Queensland Regional Plan 2009-2031. Brisbane: Department of Infrastructure and Planning,.

Saldivar-Tanaka, L. and Krasny, M. 2004. Culturing community development, neighborhood open space, and civic agriculture: The case of Latino community gardens in New York City. Agriculture and Human Values, 21(4), 399-412.

Satterthwaite, D., McGranahan, G. and Tacoli, C. 2010. Urbanization and its implications for food and farming. Philosophical Transactions of the Royal Society B: Biological Sciences, 365, 2809-2820.

Schmelzkopf, K. 1996. Urban community gardens as contested space. Geographical Review, 85(3), 364-381. 
Schmelzkopf, K. 2002. Incommensurability, land use, and the right to space: community gardens in New York City. Urban Geography, 23(4), 323-343.

Searle, G. 2010. Too concentrated? The planned distribution of residential density in SEQ. Australian Planner, 47(3), 135-141.

Shinew, K., Glover, T. and Parry, D. 2004. Leisure spaces as potential sites for interracial interaction: community gardens in urban areas. Journal of Leisure Research, 36(3), 336-356.

Somerset, S., Ball, R., Flett, M. and Geissman, R. 2005. School-based community gardens: Re-establishing healthy relationships with food. Journal of the Home Economics Institute of Australia, 12(2), 25-33.

Staeheli, L., Mitchell, D. and Gibson, K. 2002. Conflicting rights to the city in New York's community gardens. GeoJournal, 58(2), 197-205.

Stocker, L. and Barnett, K. 1998. The significance and praxis of community-based sustainability projects: Community gardens in Western Australia. Local Environment, 3(2), 179-189.

Tan, L. H. H. and Neo, H. 2009. "Community in bloom": Local participation of community gardens in urban Singapore. Local Environment, 14(6), 529-539.

Taylor, J. R. and Lovell, S. T. 2012. Mapping public and private spaces of urban agriculture in Chicago through the analysis of high-resolution aerial images in Google Earth. Landscape and urban planning, 108(1), 57-70.

Turner, B. 2011. Embodied connections: sustainability, food systems and community gardens. Local Environment, 16(6), 509-522.

Turner, B., Henryks, J. and Pearson, D. 2011. Community gardens: sustainability, health and inclusion in the city. Local Environment, 16(6), 489-492.

Twiss, J., Dickinson, J., Duma, S., Kleinman, T., Paulsen, H. and Rilveria, L. 2003. Community gardens: lessons learned from California Healthy Cities and Communities. American Journal of Public Health, 93(9), 1435-1438. 
Veteto, J. R. and Lockyer, J. 2008. Environmental anthropology engaging permaculture: Moving theory and practice toward sustainability. Culture \& Agriculture, 30(1 \& 2), 47-58.

Voicu, I. and Been, V. 2008. The effect of community gardens on neighboring property values. Real Estate Economics, 36(2), 241-283.

Wade, I. 1987. Community food production in cities of the developing nations. Food and nutrition Bulletin, 9(2), 29-36.

Wakefield, S., Yeudall, F., Taron, C., Reynolds, J. and Skinner, A. 2007. Growing urban health: Community gardening in South-East Toronto. Health Promotion International, 22(2), 92-101.

Wills, J., Chinemana, F. and Rudolph, M. 2009. Growing or connecting? An urban food garden in Johannesburg. Health Promotion International, 25(1), 33-41.

Yiridoe, E. K. and Anchirinah, V. M. 2005. Garden production systems and food security in Ghana: Characteristics of traditional knowledge and management systems. Renewable Agriculture and Food Systems, 20(03), 168-180. 


\section{Endnotes}

\footnotetext{
'The Queensland State Government, under the aegis of the South East Queensland Regional Plan, also explicitly supports the establishment of community gardens as a spatial planning response to rapid growth, intended to foster ‘safe and healthy communities’ (Queensland Government, 2009: 80-81).

${ }^{\text {ii }}$ In most cases, after five result pages additional websites were either not relevant or repeated previous results.

iii The collective values held by the organisation that act as a guiding principle for gardener behaviour.

${ }^{\text {iv }}$ Skills acquired through direct experience which help individuals to cope with problems commonly encountered in daily life.

${ }^{\mathrm{v}}$ Cover crop planted specifically to be cut and returned to the soil as high-quality organic matter.

${ }^{v i}$ At this stage however, the amount of food miles cannot be quantified since data about the productivity of the gardens (in terms of tonnes of vegetables produced etc.) was not collected. Future research should investigate this potential benefit of community gardens by quantifying carbon offsets and the like.
} 